\title{
Perceptions of Graduate Students at the University of São Paulo about Plagiarism Practices in Academic Works
}

\author{
MARCELO KROKOSCZ ${ }^{1}$ and SUELI M.S.P. FERREIRA ${ }^{2}$ \\ ${ }^{1}$ Fundação Escola de Comércio Álvares Penteado/FECAP, Av. Liberdade, 532, 01502-001 São Paulo, SP, Brazil \\ ${ }^{2}$ Universidade de São Paulo/USP, Av. Prof. Lúcio Martins Rodrigues, 443, 05508-020 São Paulo, SP, Brazil \\ Manuscript received on February 27, 2018; accepted for publication on August 20, 2018
}

\begin{abstract}
How to cite: KROKOSCZ M AND FERREIRA SMSP. 2019. Perceptions of Graduate Students at the University of São Paulo about Plagiarism Practices in Academic Works. An Acad Bras Cienc 91: e20180196. DOI 10.1590/00013765201920180196.

Abstract: Our objective was to identify the understanding of theoretical aspects and the interpretation of practical situations that a sample of 3,623 graduate students (Population $=22,438$ ) at the University of São Paulo (Brazil) have regarding academic plagiarism. The survey used an electronic questionnaire containing 30 multiple choice questions developed from the literature concerning the concept and definition of plagiarism, occurrence modality, types of plagiarism, reasons for occurrence, standards and preventive actions adopted. We identified that the fact of respondents agreeing or disagreeing with the theoretical-conceptual characteristics of plagiarism did not make a difference in their capacity of correctly assessing practical situations characterizing plagiarism. Moreover, the agreement or disagreement responses regarding the concepts of plagiarism were observed not to differ among the respondents who had been trained to use references and citations. However, the same respondents correctly interpret practical situations characterizing plagiarism. Therefore, this study suggests that there is a gap between theoretical and practical knowledge regarding plagiarism for graduate students. Although the technical training related to the correct use of research sources is an important prerequisite in the capacity-building process, it does not seem to be enough to prevent plagiarism practices.
\end{abstract}

Key words: academic plagiarism, graduate students, research integrity, writing skills.

\section{INTRODUCTION}

Notwithstanding the comprehensiveness of international studies into the occurrence of dishonest attitudes and plagiarism in the academic environment, it can be admitted that little is still known about the incidence and characterization of the problem among graduate students (Mccabe et al. 2006, Gilmore et al. 2010). Yet, furthering the

Correspondence to: Marcelo Krokoscz

E-mail: marcelok@fecap.br

ORCid: https://orcid.org/0000-0002-6869-864X studies in this area, Mccabe et al. (2006) verified that the problem exists. Among graduate students in the business area, dishonest attitudes, as is the case of plagiarism, are more common than with scholars in other areas. One of the reasons for this may be the fact that the students in the business area think that cheating as something not very serious. The authors' results suggest that students or faculty don't support academic integrity, as well the existence of a correlation between academic dishonesty and the recognition that cheating is not reported by other students (Mccabe et al. 2006). 
Gilmore et al. (2010) investigated the rates and possible reasons for the occurrence of plagiarism in master's and $\mathrm{PhD}$ programs. They observed that plagiarism is a common problem to all the areas. However, it is mainly related with students who have English as their second language. This is generally characterized as non-intentional and derives from personal difficulties in the form of using primary literature in their theoretical foundation, an aspect in relation to which the adoption of training strategies is suggested viewing the improvement of research techniques (Gilmore et al. 2010). Likewise, findings from another research demonstrate that the high-level skills to write in English is a competence only few scientific writers have (Vasconcelos et al. 2009).

Nevertheless, writing scientific papers in English is also recognized as a challenging issue for both native and non-native speakers of English. The art of writing scientific texts requires effective skills, such as accuracy and objectivity for using words and sentences. Due to the complexity of the English Language, recommendations such as writing skills and support of professional writers can help to solve problems regarding the use of jargons and confuse terms (Eberle 2013).

For Pecorari (2003), plagiarism among graduate students is more closely related to a practice that occurs for accidental reasons rather than intentional. Citing Howard (2001), Pecorari (2003) argues that plagiarism among graduate students refers to something connected to the interest to improve as a writer. Pecorari (2003) adds that it is also related to the fact that these students do not know how to acknowledge the sources surveyed according to the requirements of academic convention. Despite these observations, this author stresses that those participating in the study, although they seem to be excellent students, did not consider that there could be plagiarism in their works.
However, it is interesting to contrast Pecorari's observations with the results from the study conducted by Moore (2013) on the ability of Finland students to give credit to sources mentioned in their theses. Even though the author mentions the Finnish educational quality acknowledged around the world, added to the fact that the students can find writing guidelines on the websites of all higher education institutions, he verified that a significant number of theses had problems related to referencing the sources used. The author concludes that there is a gap between the requirements to academic writing and how students understand plagiarism.

This gap that seems to exist between what is understood as plagiarism and what happens in practice is an aspect that triggers the development of new researches and further debate. One of the possible reasons associated to that is the lack of knowledge of or misunderstanding of what characterizes academic plagiarism. Roig (2006) argues that plagiarism is a complex concept because there are different ideas within the academy regarding what constitutes plagiarism. See, for example, the study conducted with graduated students of a public university in Brazil into plagiarism and scientific writing skills, which verified the lack of knowledge of the participants regarding the concept of plagiarism, the existence of problems related to the acknowledgement of the sources consulted and the lack of quality of the paraphrases (Ferreira and Santos 2011).

Another reason could be the mistaken idea that students are able to write manuscripts giving credits correctly just because they were trained in academic writing (Foltýnek et al. 2014). The authors suggest that to help students to avoid plagiarism, it is important to consider the perception of plagiarism and the students' educational needs (Foltýnek et al. 2014).

These observations are corroborated by the results found in an opinion survey study performed with graduated students of a University in the 
south of Brazil. The authors verified that even though the students had declared they knew what constituted plagiarism, this was observed to be a kind of intuitive knowledge unrelated to the academic learning process. The research results evidenced that the participants did not master the rules for citing the sources consulted (Fachini and Domingues 2008).

The same results were found in a search conducted with graduate students of a private institution in another Brazilian State. The students depicted a clear knowledge of the concept of plagiarism; nevertheless they demonstrated not to how to cite and reference correctly other authors (Silva and Domingues 2008). Another study has found about $33 \%$ of graduate students that said they were rarely or never trained on plagiarism (Santos et al. 2017).

Considering this scenario, the question is if the fact that graduate students have received some sort of instruction or guidance concerning plagiarism in the academic environment is associated with a higher level of enlightenment when faced with practical situations related to plagiarism. In addition, we ask if the fact that they have had learned how the sources consulted should be acknowledged with adequate citations and references is associated with the ability of adequately analyzing and interpreting practical examples. If aspects such as guidance and training have no association with the adequate interpretation of situations characterizing academic plagiarism, what aspects can be identified as meaningful in this case? Thus, among so many questions still with no conclusive answers, this study main objective is to identify the existence of associations between theoretical and practical knowledge in academic plagiarism of a sample of 3,623 graduate students of the University of São Paulo (Brazil).

The results are expected to contribute to understanding the plagiarism phenomenon within these students' profile to improve the possibilities to combat and to reduce the occurrence of plagiarism among this population.

\section{MATERIALS AND METHODS}

This study was conducted by a team of researchers in a partnership with the Provost Office for Graduate Studies of the University of São Paulo (USP) and the board of the USP Integrated Library System 2010/2013.

The University of São Paulo (http://www.usp. br) is the biggest university in Brazil, located at São Paulo State. This public university, has 30.000 graduate students, more than 58.000 undergraduate students, 7.000 professors and approximately 18.000 staff. USP is the highest ranked Latin American university in several international rankings, for instance, the World University Ranking of 20172018, published by British consultancy Times Higher Education (THE); USP is the 77th best university in the world, according to the ranking published 2018, published by the consultancy Center for World University Rankings (CWUR), the United Arab Emirates, and so on. The university created in 2015 an Academic Integrity Commission, which, among other activities, develops educational programs to combat plagiarism. Few online course for undergraduate and graduate students have been offered since then. The concern with the integrity of this academic production (thesis, dissertations and scientific articles in national and international journals) motivated the systematically offer of specialized workshops on the topic, the acquisition of tools to identify and combat plagiarism in the University (such as Originality Check -Turnitin), and the creation of the Laboratory of Good Scientific Practices.

The initial scope of the project was to conduct an exploratory survey on the perception the institution graduate students $(\mathrm{N}=22,438)$ had of the academic plagiarism phenomenon. The survey, adopted the Survey Monkey tool (http:// 
surveymonkey.com/), was carried out by means of an electronic questionnaire containing 30 multiple choice questions, divided into three parts. In the first, 14 questions were presented regarding theoretical knowledge of plagiarism (concepts, types, forms of occurrence among other aspects); in the second part, 10 practical situations were presented concerning plagiarism and the use of sources that required the respondents' analysis and interpretation; the third part contained questions on the respondents' profile (Appendix) ${ }^{\mathbf{1}}$.

The theoretical and practical parts of the questionnaire were developed from the principles and orientations conventionalized by the literature regarding plagiarism concept and definition (Australian Government 2007, U.S. Department of Health and Human Services 2005, United Kingdon Research Council UK 2011), occurrence modalities (Green 2002, Pecorari 2003, Gilmore et al. 2010, Roig 2011), types of plagiarism (Harris 2001, Loui 2002, Maxwell et al. 2008, Roig 2011, Plagiarism. org 2013), reasons for occurrence (Mccabe and Trevino 1997, Harris 2001, Mccabe et al. 2006, Power 2009, Curtis and Popal 2011, Sauthier et al. 2011), standards and preventive actions adopted (Mccabe et al. 2001, 2002, Pecorari 2003, Mccabe and Pavela 2005).

Before distributing the questionnaire to the population studied, a pre-test was conducted with seven graduate students, which observed aspects such as the time spent on answering, length of the questionnaire, level of difficulty in answering and the clarity of the statements.

The dissemination of the research questionnaire and the call for participation were made via an e-mail message, containing the link to access the questionnaire, forwarded by the University Department of Information Technology to all the USP graduate students.

\footnotetext{
${ }^{1}$ It is a translation from the original in Portuguese.
}

Despite this study was not submitted by an Ethics Committee, all students were informed about the relevance and aims of this study as well, they were advised about the anonymity of the online survey, which did not allow any recognition of respondents. All participants answered the questionnaire freely and without any kind of payment.

The electronic questionnaire remained online from November 21, 2012 to January 30, 2013, totaling 71 days of availability. Along this period, responses from 3,623 participants were obtained, which is equivalent to $16.14 \%$ of the population studied, characterizing a non-probabilistic sample.

The analyses of the findings are presented in absolute and relative frequencies. The association of each question related to the theoretical knowledge of plagiarism (section A) with each one related to the analyses of practical situations concerning plagiarism (section B) is evaluated with Pearson's Chi-squared test (Pearson 1900, Fisher 1922). Conditional independence of association from section A and B controlled by the demographic questions was measured with Cochran-MantelHaenszel test (Cochran 1954). To protect against the increase of type I error due to multiple-choice testing, the conservative Bonferroni correction was applied (Bonferroni 1935). Nominal type I error for the study is set at 5\% and all the analyses were conducted on R 3.0.2 (a free statistical software).

The analyses considered only the valid answers (blank responses or duplicates were discarded).

\section{RESULTS AND DISCUSSION}

The sample age range lies mainly in the 26-30 range (40\%), followed by age ranges of 31 to 35 (20\%) and 20 to 25 (19\%) which allows observing that $4 / 5$ of the respondents comprise an age range with a maximum variation of 15 years. Regarding the respondents' gender, there was a greater participation of females $(56 \%)$ as compared to 
males $(44 \%)$. In relation to the level of study, the largest proportion was of $\mathrm{PhD}$ students $(55 \%)$ as compared to academic master's students (43\%) and professional master's students (2\%). Most respondents studied full-time with a grant $(59.4 \%)$ or without a grant $(8.8 \%)$, worked part-time $(15 \%)$ or worked full-time (16.8\%). Only $3.6 \%$ of the respondents were not Brazilian, and among these $72 \%$ were Latin-Americans. Table I shows the percentage of respondents as per area of studies.

Concerning the modalities of plagiarism occurrence, $65 \%$ fully agree and agree that students usually commit plagiarism accidentally "for not knowing how to correctly indicate the author and to identify the source used" (Question 4) where as $72 \%$ fully agree and agree that students usually commit plagiarism intentionally, be it comparing completed works, copying from the internet or using works by their peers. Actually, 22.19\% of the respondents declared to have known a graduate course colleague whom they perceived to have committed plagiarism intentionally.

Despite this, this study allowed verifying that this practice is more attributed to the desire of attaining good academic results $(28.21 \%)$, which does not differ from studies of factors leading to the occurrence of plagiarism among undergraduate students (Curtis and Popal 2011, Power 2009, Bennett 2005). Those results were different in some researches where reasons have been presented for the occurrence of plagiarism as an accidental problem due to difficulties with the English language for non-native speakers (Vasconcelos et al. 2009, Gilmore et al. 2010), native speakers (Eberle 2013) or with academic writing (Howard 2001, Pecorari 2003). Therefore, in this sample, after the desire to achieve good academic outcomes, followed by the difficulty in writing texts $(17.53 \%)$ and the lack of standards to control and to punish plagiarism practice $(14.63 \%)$.

When asked about the "actions adopted by the higher education institutions at which they had studied aiming to inform and to guide students so that academic plagiarism was prevented", only $14.66 \%$ of the respondents indicated that "the institution had regulation, rules and penalties clearly informed to students", whereas more than half of the respondents $(67.38 \%)$ claimed "not to remember any specific activity at the institution, adopted aiming to inform and to guide students for them to prevent the occurrence of academic plagiarism". These findings are consistent with the

TABLE I

Participants in the study as per area of studies.

\begin{tabular}{cccc}
\hline Question 28 & Frequency & Percentage & \% Valid \\
\hline Humanities & 574 & 15.84 & 16.41 \\
Applied Social Sciences & 296 & 8.17 & 8.46 \\
Linguistics, Languages and Arts & 232 & 6.40 & 6.63 \\
Health Sciences & 689 & 19.02 & 19.70 \\
Biological Sciences & 449 & 12.39 & 12.84 \\
Agricultural Sciences & 182 & 5.02 & 5.20 \\
Exact and Earth Sciences & 483 & 13.33 & 13.81 \\
Engineering & 395 & 10.90 & 11.30 \\
Multidisciplinary & 197 & 5.44 & 5.63 \\
Valid & 3497 & 96.52 & 100.00 \\
Missing & 126 & 3.48 & 100.00 \\
\hline
\end{tabular}


results in Santos et al. (2017) which showed that students "did not receive or rarely receive guidance on plagiarism in their graduate courses".

Despite a significant number of participants (41.01\%) of our study consider that "the most efficient actions to prevent plagiarism in academic activities" are those of "educational [character], directed towards prevention, such as lectures, talks, seminars". Although this seems sufficient to avoid plagiarism because, as stated by Foltýnek et al. (2014) "better training in academic writing" does not exactly mean "to be able to write assignments without having to resort plagiarism". However, for $19.94 \%$ of the respondents, the "institutional actions, such as the adoption of codes of honor, guidance handbooks and presentation of institutional policies" are the most adequate action to avoid plagiarism. It is interesting, because some research has found that the adoption of "honor codes are associated with lower levels of student dishonesty" (Mccabe et al. 2002, Mccabe and Pavela 2005).

To verify the association of theoreticalconceptual knowledge with analysis and practical interpretation, statistical tests were performed with some of the questionnaire questions as presented in Table II. The theoretical questions were presented with a five-item Likert Scale: fully agree, agree, indifferent, disagree and fully disagree. The practical questions were presented with yes-no dichotomic alternatives.

In Table III, the results demonstrate an association between the responses given in the two groups of questions, that is, they suggest that respondents who erroneously fully disagree with the concepts related to plagiarism tend to respond correctly (option no) when faced with practical situations (Question 1 versus Question 16; Question 1 versus Question 17; Question 2 versus Question 16; Question 2 versus Question 17). Nevertheless, the results also show that respondents who correctly fully agreed with the concepts and characteristics describing plagiarism, also responded correctly when faced with practical situations requiring this knowledge (Question 3 versus Question 16 and Question 3 versus Question 17).

Even though a large share of those responding to these questions correctly answered "no" when faced with practical situations, it is worth noting that there is no coherence between their fully agreeing or disagreeing with the concept or characteristics of what is considered academic plagiarism as described in questions one, two and three. This suggests that the theoretical-conceptual knowledge seems to be indifferent when interpreting a practical situation, showing that there seems to be more clarity concerning the interpretation of practical questions than theoretical ones.

Considering previous studies on the subject conducted with international students (Foltýnek et al. 2014) and Brazilian students, who evidenced the lack of theoretical knowledge on the subject (Ferreira and Santos 2011) and dissociation between theoretical and practical knowledge (Silva and Domingues 2008, Fachini and Domingues 2008), this findings reiterates this difference, in which the fact of agreeing or disagreeing with theoreticalconceptual characteristics of plagiarism was observed not to differ from the ability of correctly evaluating practical situations characterizing plagiarism.

However, if that were the case, this would be incompatible with the results verified in the response of the participants who said that at some point in their studies they had learned how to make citations and references of texts/research sources used in academic works (Question 12) and that they agree that graduate students are capable of preventing plagiarism in academic works (Question 13). As shown in Table IV, the rate of agreement regarding the sense of preparedness for preventing plagiarism is verified to be $67.8 \%$.

Hence, associations were made between Question 1, Question 2, Question 16 and Question 
TABLE II

Questions in the questionnaire about theoretical and practical knowledge regarding academic plagiarism.

Theoretical-conceptual knowledge

Question 1. Plagiarism is: "Signing or presenting as yours (artistic or scientific work by someone else). Imitating (someone's work)".

( ) Fully agree.....

( ) Fully disagree

Question 2. Literally copying (word by word) a paragraph from a text without making any identification of the source consulted is plagiarism.

( ) Fully agree............( ) Fully disagree

Question 3. Writing a paragraph using sentences from other texts, presenting the sources consulted solely in the list of references at the end of the work is plagiarism.

( ) Fully agree............( ) Fully disagree

\section{Analysis and practical interpretation}

Question 16. May a student be elaborating the text of his/her research report rewrite with his/her own words a reflection by another author without citing the source?

( ) yes ( )no

Question 17. May a student literally transcribe a text from another source without using quotation marks or within reduced margins, provided he/she indicates the original source with the author-date or numerical system?

( ) yes ( )no

TABLE III

Pearson's Chi-squared Test - Compared Questions.

\begin{tabular}{|c|c|c|c|c|c|}
\hline & Fully agree * No & Fully disagree $*$ No & Statistics & G.I. & Value-p \\
\hline $\begin{array}{l}\text { Question } 1 \mathrm{x} \\
\text { Question } 16\end{array}$ & $87.5 \%$ & $95.7 \%$ & 42.561 & 8 & $<0.001$ \\
\hline $\begin{array}{l}\text { Question 1x } \\
\text { Question } 17\end{array}$ & $70.8 \%$ & $78.3 \%$ & 36.214 & 8 & $<0.001$ \\
\hline $\begin{array}{l}\text { Question } 2 \mathrm{x} \\
\text { Question } 16\end{array}$ & $88.7 \%$ & $93.8 \%$ & 36.214 & 8 & $<0.001$ \\
\hline $\begin{array}{l}\text { Question } 2 \mathrm{x} \\
\text { Question } 17\end{array}$ & $72.2 \%$ & $87.5 \%$ & 75.488 & 8 & $<0.001$ \\
\hline $\begin{array}{l}\text { Question } 3 x \\
\text { Question } 16\end{array}$ & $92.6 \%$ & $73.0 \%$ & 136.827 & 8 & $<0.001$ \\
\hline $\begin{array}{l}\text { Question } 3 \mathrm{x} \\
\text { Question } 17\end{array}$ & $80.6 \%$ & $48.4 \%$ & 166.508 & 8 & $<0.001$ \\
\hline
\end{tabular}

TABLE IV

Pearson's Chi-squared Test for Questions 12 versus Question 13.

\begin{tabular}{|c|c|c|c|c|c|c|c|c|}
\hline & & & & & QUEST & N 13 & & \\
\hline & & & $\begin{array}{c}\text { Fully } \\
\text { disagree }\end{array}$ & Disagree & Indifferent & Agree & $\begin{array}{l}\text { Fully } \\
\text { agree }\end{array}$ & Total \\
\hline QUESTION 12 & Yes & Frequency & 56 & 650 & 311 & 1337 & 812 & 3166 \\
\hline & & $\%$ & $1.8 \%$ & $20.5 \%$ & $9.8 \%$ & $42.2 \%$ & $25.6 \%$ & $100.0 \%$ \\
\hline & No & Frequency & 47 & 212 & 79 & 98 & 19 & 455 \\
\hline & & $\%$ & $10.3 \%$ & $46.6 \%$ & $17.4 \%$ & $21.5 \%$ & $4.2 \%$ & $100,0 \%$ \\
\hline & TOTAL & Frequency & 103 & 862 & 390 & 1435 & 831 & 3621 \\
\hline & & $\%$ & $2.8 \%$ & $23.8 \%$ & $10.8 \%$ & $39.6 \%$ & $22.9 \%$ & $100.0 \%$ \\
\hline
\end{tabular}


17 with Question 12 which asked if "at any point of the studies conducted so far, the student has learned how to make citations and references of texts/research sources used in academic works". The associations presented in Table $\mathrm{V}$ allowed identifying that the percentage of "disagree" (Question 1 and Question 2) and those who marked "no" in Question 16 and in Question 17 tend to be a little larger in Question 12 as compared to the percentage of respondents who "agree". This result suggests that the respondents who disagree with the concepts of plagiarism presented in Question 1 and Question 2, but who correctly analyzed Question 16 and Question 17 represent a larger percentage of respondents who admit having learned how to make citations and references (Question 12).

This table evidences that the participants who did not correctly respond to conceptual questions about plagiarism but who managed to correctly interpret the plagiarism situations presented, are exactly those who indicated to have been trained to use citations and references (Question 12/ How responded "Yes").

Moreover, our study verified that the answers of those students, that inform to have received information about how to academically use citations and references, are associated to the opinion of being able to prevent plagiarism. However, it is not associated with the answers regarding agreement or disagreement concerning the conceptual characteristics of plagiarism, notwithstanding their corresponding to the correct interpretation made of practical situations describing cases of plagiarism. Although, the literature shows that better training in academic writing is not enough to prevent plagiarism in students' assignments (Foltýnek et al. 2014), this study can only present this assumption as something to consider since the academic writing training at USP is not something mandatory for all students ${ }^{2}$.

${ }^{2}$ Since 2011, USP Pro-Rector of Research has been
To find an association between correct theoretical knowledge and correct practical analysis, the answers given to item 6 ("I do not remember any specific activity at the institution that has been adopted regarding information and guidance for students to prevent the occurrence of academic plagiarism") were investigated regarding the question about "the actions adopted by the higher education institutions at which the respondent studied and which aimed to inform and to guide students towards preventing academic plagiarism" (Question 14).

Over half of the respondents $(67.38 \%)$ marked item 6 which corresponded to the option "I do not remember any specific activity from the institution that has been adopted regarding information and guidance for students to prevent the occurrence of academic plagiarism." However, analyzing the responses given to Question 14 in Table VI, as compared to the responses given to Question 1, Question 2, Question 16 and Question 7, no marked differences are evidenced between those who do not remember ( 0 ) having received specific guidance concerning plagiarism and those who do (1).

systematically promoting Workshops in the three areas of knowledge (exact, biological and human) in an itinerant way, covering all the campuses of countryside and capital. Each workshop (started in partnership with FAPESP and Publics Company but now under the responsibility of the Integrated Library System and several publishers and companies) provides for the introduction of techniques and concepts of Scientific Writing with emphasis on English Language, aiming to assist / enable participants in the process of writing a scientific paper. The main objective was to help the target audience (teachers and graduate students) understand the characteristics and conventions of the academic genre, and to develop the skills needed to express their ideas and arguments effectively (http: //www.sibi .usp.br / initiatives / education-in-information / actions /). Nowadays, the USP Campus community in São Carlos maintains the Scientific Writing Portal, a repository of information related to Projects, Methodology, Management, Writing and Publishing of Scientific Articles, and that served as a guide for students and researchers interested in improving their skills in the area (http://www.escritacientifica.sc.usp.br/). 
Therefore, according to these results, it seems that the fact of having received information or guidance concerning plagiarism (Question 14/1) does not make much difference regarding the fact of agreeing or disagreeing with the conceptual knowledge of plagiarism. See that the percentage of answers is close. Moreover, it is worth highlighting that both group of answers (Question 14/0 and Question 14/1) are related to correct analyses of a practical situation that characterizes plagiarism. Also, the fact of remembering or not to have received guidance and information on plagiarism was verified not to present differences regarding the percentage of respondents who agreed or disagreed with the issues defining or theoretically characterizing plagiarism. Hence, this study stresses the idea that there is a gap between theoretical and practical knowledge concerning plagiarism, an observation made in Brazilian studies, but which was been raised by international studies (Moore 2013, Foltýnek et al. 2014).

Some implications related to this dissociation between theoretical and practical knowledge may be the occurrence of accidental plagiarism, a common modality of involvement in which individuals do not know they are doing plagiarism once they do not know the rules, the concepts, the characteristics or the types of plagiarism. Maybe for this reason, the respondents of this study considered that plagiarism occurs more for intentional than for accidental reasons. Moreover, the knowledge received in the writing practices may be dissociated from the characterization of plagiarism and perhaps even mischaracterized by the prominence that may be given to the use of such techniques simply relating them to the author visibility ends.

Aiming to outline the respondents' profile according to the standard of responses observed, Table VII presents the associations of the responses given to the group of conceptual (answer: fully agree) and practical (answer: no) questions with the respondents' profile. No significant association was found between the responses given to questions Question 1 versus Question 16 and Question 1 versus Question 17 as compared to the questions about the respondents' profile (Question 25: age; Question 26: gender; Question 27: course; Question 28: area; Question 29: nationality; Question 30: occupation). Yet the analyses showed significant associations $(\mathrm{p}<0.001)$ for the analyses presented as follows:

These results suggest that the respondents' profile with the most adequate standard of responses as regards the responses expected in the associations between theoretical and practical knowledge is a Brazilian subject in the 36 to 40 age

TABLE V

Larger percentage verified for respondents who marked "fully agree" and "fully disagree" (Question 1 and Question 2) versus "no" (Question 16 and Question 17) crossed with the responses to Question 12.

\begin{tabular}{|c|c|c|c|c|c|c|c|c|}
\hline & \multicolumn{2}{|c|}{$\begin{array}{l}\text { Question } 1 \text { versus } \\
\text { Question } 16\end{array}$} & \multicolumn{2}{|c|}{$\begin{array}{l}\text { Question } 1 \text { versus } \\
\text { Question } 17\end{array}$} & \multicolumn{2}{|c|}{$\begin{array}{l}\text { Question } 2 \text { versus } \\
\text { Question } 16\end{array}$} & \multicolumn{2}{|c|}{$\begin{array}{l}\text { Question } 2 \text { versus } \\
\text { Question } 17\end{array}$} \\
\hline & $\begin{array}{l}\text { Fully } \\
\text { agree } \\
\text { versus No }\end{array}$ & $\begin{array}{l}\text { Fully } \\
\text { disagree } \\
\text { versus No }\end{array}$ & $\begin{array}{l}\text { Fully agree } \\
\text { versus No }\end{array}$ & $\begin{array}{l}\text { Fully } \\
\text { disagree } \\
\text { versus No }\end{array}$ & $\begin{array}{l}\text { Fully agree } \\
\text { versus No }\end{array}$ & $\begin{array}{l}\text { Fully } \\
\text { disagree } \\
\text { versus No }\end{array}$ & $\begin{array}{l}\text { Fully agree } \\
\text { versus No }\end{array}$ & $\begin{array}{l}\text { Fully } \\
\text { disagree } \\
\text { versus No }\end{array}$ \\
\hline $\begin{array}{l}\text { Question } 12 \\
\text { Yes }\end{array}$ & $89.1 \%$ & $94.7 \%$ & $72.4 \%$ & $73.7 \%$ & $73.2 \%$ & $84.6 \%$ & $89.8 \%$ & $92.3 \%$ \\
\hline $\begin{array}{l}\text { Question } 12 \\
\text { No }\end{array}$ & $75.6 \%$ & $100 \%$ & $58.9 \%$ & $100 \%$ & $64.4 \%$ & $100 \%$ & $80 \%$ & $100 \%$ \\
\hline
\end{tabular}

Cochran Test-Mantel-Haenszel. Value: $\mathrm{p}<0.001$. 
range, female, $\mathrm{PhD}$ student of a multidisciplinary area exerting a professional occupation in part-time regime.

Table VIII presents the associations of the responses given to the set of conceptual (I fully agree or disagree response) and practical (yes response) questions presented in Table II with the respondents' profile. The analyses showed the significant associations $(p<0.001)$ for the crossings presented as follows:

Cochran-Mantel-Haenszel Test. Value-p < 0.001 .

These results suggest that the respondents' profile with a more inadequate standard of responses as regarding the responses expected in the associations between theoretical and practical knowledge correspond to a Brazilian subject, between 36 and 40 of age, female, PhD student in the social sciences area, studying full time.

\section{CONCLUSIONS}

In summary, this study suggests that the challenge of the efficacy of the strategies to fight plagiarism seems to go beyond the mere conceptual orientation regarding plagiarism, the instrumental training for academic writing or even providing information on what characterizes plagiarism. Even though these strategies should be considered important and necessary, they seem to be insufficient to combat plagiarism in the academic environment, seeing the permanence and the incidence rate of this problem. One possible important aspect to be considered facing this study is the understanding highlighted by Eberle (2013): "Many students consider writing to be the least enjoyable part of the scientific process, [whereas] developing your best writing skills comes through a lifetime of learning and improvement".

Besides, making efforts to prevent plagiarism is better than simply detecting and punishing. Roig (2006), citing Kolin (2002), emphasizes that "instruction on plagiarism should focus on the principles of ethical writing", that is, underlying the text, there is a contract between the writer and the reader stating that what is presented is "accurately and objectively represented to the best of our ability".

We conclude that although the technical training regarding the correct use of research sources is an important prerequisite in the capacity building process, it is insufficient to prevent academic plagiarism. As from this observation, the reflection on the aspects related to the gap between what is known (theoretical knowledge) and what is done (practical action) regarding plagiarism seems to be a promising trend for other studies, which may produce new results to contribute to preventing and to reducing the occurrence of academic plagiarism or even than challenging our comprehension on plagiarism.

Considering that in this study was found that although technical training related to the correct use of research sources is an important prerequisite in the capacity-building process, it is not enough for academic plagiarism to be prevented; perhaps it is time to reconsider what exactly plagiarism is in the academic field. The most important objective in scientific writing is the original content and the words utilized are just resources to communicate a scientific idea or finding with accuracy and objectivity (Habibzadeh and Shashok 2011). Hence, new studies on the reason to cite or to give credits in scientific texts are recommended. It could directly affect the manner guidelines are defined as well as how the renewal of the ethics in publications is established. The problems regarding academic plagiarism may not merely be related to who owns the words, but the propriety (accuracy) more than property (ownership), how they are utilized in this sharing era. 
TABLE VI

Larger percentage verified for respondents who marked "fully agree" and "fully disagree" (Question 1 and Question 2) versus "no" (Question 16 and Question 17) crossed with the responses to Question 14 according to those who marked item $6(0=$ no $)$ and those who marked item $6(1=$ yes $)$.

\begin{tabular}{|c|c|c|c|c|c|c|c|c|}
\hline & \multicolumn{2}{|c|}{$\begin{array}{l}\text { Question } 1 \text { versus } \\
\text { Question } 16\end{array}$} & \multicolumn{2}{|c|}{$\begin{array}{l}\text { Question } 1 \text { versus } \\
\text { Question } 17\end{array}$} & \multicolumn{2}{|c|}{$\begin{array}{l}\text { Question } 2 \text { versus } \\
\text { Question } 16\end{array}$} & \multicolumn{2}{|c|}{$\begin{array}{l}\text { Question } 2 \text { versus } \\
\text { Question } 17\end{array}$} \\
\hline & $\begin{array}{l}\text { Fully agree } \\
\mathrm{x} \text { No }\end{array}$ & $\begin{array}{l}\text { Fully } \\
\text { disagree } \mathrm{x} \\
\text { No }\end{array}$ & $\begin{array}{l}\text { Fully agree } \\
\text { x No }\end{array}$ & $\begin{array}{l}\text { Fully } \\
\text { disagree } \mathrm{x} \\
\text { No }\end{array}$ & $\begin{array}{l}\text { Fully agree } \\
\mathrm{x} \text { No }\end{array}$ & $\begin{array}{l}\text { Fully } \\
\text { disagree } \mathrm{x} \\
\text { No }\end{array}$ & $\begin{array}{l}\text { Fully agree } \\
\mathrm{x} \text { No }\end{array}$ & $\begin{array}{l}\text { Fully } \\
\text { disagree } \mathrm{x} \\
\text { No }\end{array}$ \\
\hline $\begin{array}{l}\text { Question } 14 \\
\text { 0 = No }\end{array}$ & $87.3 \%$ & $100 \%$ & $74.4 \%$ & $90.0 \%$ & $88.0 \%$ & $100 \%$ & $75.1 \%$ & $100 \%$ \\
\hline $\begin{array}{l}\text { Question } 14 \\
1=\text { Yes }\end{array}$ & $87.7 \%$ & $92.3 \%$ & $69.1 \%$ & $69.2 \%$ & $89.0 \%$ & $88.9 \%$ & $70.7 \%$ & $77.8 \%$ \\
\hline
\end{tabular}

Cochran Test-Mantel-Haenszel. Value: $\mathrm{p}<0.001$.

TABLE VII

Larger percentage verified for respondents who marked "fully agree" (Question 2 and Question 3) versus "no" (Question 16 and Question 17) crossed with the responses to the questions with profile characteristics.

\begin{tabular}{|c|c|c|c|c|}
\hline & $\begin{array}{l}\text { Question } 2 \text { versus } \\
\text { Question } 16\end{array}$ & $\begin{array}{l}\text { Question } 2 \text { versus } \\
\text { Question } 17\end{array}$ & $\begin{array}{l}\text { Question } 3 \text { versus } \\
\text { Question } 16\end{array}$ & $\begin{array}{l}\text { Question } 3 \text { versus } \\
\text { Question } 17\end{array}$ \\
\hline Question 25: age & aged 36 to $40: 92.1 \%$ & aged over $41: 75.8 \%$ & $\begin{array}{l}\text { aged } 36 \text { to } 40 \text { : } \\
95.6 \%\end{array}$ & $\begin{array}{l}\text { aged } 36 \text { to } 40 \text { : } \\
82.2 \%\end{array}$ \\
\hline Question 26: gender & Female: $89.5 \%$ & Female: $73.6 \%$ & Female: $94.0 \%$ & Female: $82.4 \%$ \\
\hline Question 27: course & PhD: $90.0 \%$ & PhD: $74.5 \%$ & PhD: $94.3 \%$ & PhD: $81.6 \%$ \\
\hline Question 28: area & Social Sciences: $93.1 \%$ & Humanities: $79.7 \%$ & $\begin{array}{l}\text { Multidisciplinary: } \\
97.1 \%\end{array}$ & $\begin{array}{l}\text { Multidisciplinary: } \\
89.7 \%\end{array}$ \\
\hline Question 29: nationality & Brazilian: $88.8 \%$ & Brazilian: $72.5 \%$ & Other: $95.7 \%$ & Brazilian: $81.2 \%$ \\
\hline Question 30: occupation & Part-time work: $90.1 \%$ & Part-time work: $74.6 \%$ & $\begin{array}{l}\text { Part-time work = } \\
92.8 \%\end{array}$ & $\begin{array}{l}\text { Full-time work: } \\
83.1 \%\end{array}$ \\
\hline
\end{tabular}

Cochran Test-Mantel-Haenszel. Value: $\mathrm{p}<0.001$.

\section{TABLE VIII}

Larger percentage verified among respondents who marked "I fully agree or disagree" (Question 2 and Question 3 ) $X$ "yes" (Question 16 and Question 17) crossed with the responses to the questions with profile characteristics.

\begin{tabular}{lllll}
\hline & $\begin{array}{l}\text { Question 2 versus } \\
\text { Question 16 }\end{array}$ & $\begin{array}{l}\text { Question 2 versus } \\
\text { Question 17 }\end{array}$ & $\begin{array}{l}\text { Question 3 versus } \\
\text { Question 16 }\end{array}$ & $\begin{array}{l}\text { Question 3 versus } \\
\text { Question 17 }\end{array}$ \\
\hline Question 25: age & aged 36 to $40: 28.6 \%$ & aged 26 to 30: $57.1 \%$ & $\begin{array}{l}\text { aged 20 to 25: } \\
21.1 \%\end{array}$ & aged 36 to 40: $50 \%$ \\
Question 26: gender & Male: $20 \%$ & Female: $46.2 \%$ & Male: $21.9 \%$ & Female: $43.6 \%$ \\
Question 27: course & PhD: $23.8 \%$ & PhD: $47.6 \%$ & Master's: $16.9 \%$ & Master's: $40.3 \%$ \\
Question 28: area & Social /Biological & Social Sciences: $100 \%$ & Engineering: & $\begin{array}{l}\text { Agricultural } \\
\text { Sciences: } 61.5 \%\end{array}$ \\
Question 29: nationality & Brazilian: $16.2 \%$ & Brazilian: $37.8 \%$ & Other: $27.3 \%$ & Brazilian: $39.5 \%$ \\
Question 30: occupation & Full-time student: $66.7 \%$ & Full-time student: & Full-time student: & Full-time student: \\
\end{tabular}

Cochran-Mantel-Haenszel Test. Value: $\mathrm{p}<0.001$. 


\section{ENLIGHTENMENT}

This research was presented, after being peer reviewed, at the " 6 th International Integrity and Plagiarism Conference: Promoting authentic assessment" (Newcastle, England, 16-18 June 2014). We declare that this paper has not been published in any journal before, although it is possible to find a previous version in some open and public repositories as $<$ http://www.producao. usp.br/handle/BDPI/45660>. The paper has now been submitted to additional double-blind peer review to this journal and, as a result of revisions and suggestions, is different from the previous version presented at the Plagiarism Conference and the text uploaded at the open repositories.

\section{AUTHOR CONTRIBUTIONS}

Both authors, Marcelo Krokoscz and Sueli Mara Soares Pinto Ferreira, are aware and follow all the recommendations given by the International Committee of Medical Journal Editors, e.g., they are responsible for "substantial contributions to the conception and design of the work; [worked on] the acquisition, analysis, and interpretation of data; and drafted the work and revised it critically; and [given] final approval of the version to be published; and both authors agree to be accountable for all aspects of the work in ensuring that questions related to the accuracy or integrity of any part of the work are appropriately investigated and resolved."

\section{REFERENCES}

AUSTRALIAN GOVERNMENT. 2007. Australian Code for the Responsible Conduct of Research. Available at: https:// www.nhmrc.gov.au/guidelines-publications/r39. Accessed on November $16^{\text {th }}, 2018$.

BENNETT R. 2005. Factors associated with student plagiarism in a post-1992 university. Assess Eval High Educ 30(2): $137-162$

BONFERRONI CE. 1935. Il calcolo dele assicurazioni su gruppi di teste. Studi in Onore del Professore Salvatore Ortu Carboni. Rome: Italy, p. 13-60.
COCHRAN WG. 1954. Some methods for strengthening the common $\chi 2$ tests. Biometrics 10: 417-451.

CURTIS GJ AND POPAL R. 2011. An examination of factors related to plagiarism and a five-year follow-up of plagiarism at an Australian university. International Journal for Educational Integrity 7(1): 30-42.

EBERLE ME. 2013. Paraphrasing, Plagiarism, and Misrepresentation in Scientific Writing. Transactions of the Kansas Academy of Science 116(3-4): 157-167.

FACHINI GJ AND DOMINGUES MJCS. 2008. Percepção do plágio acadêmico entre alunos de Programas de PósGraduação em Administração e Contabilidade. In: XI Seminários em Administração - FEA/USP, São Paulo. Available at: http://sistema.semead.com.br/11semead/ resultado/an_resumo.asp?cod trabalho $=842$. Accessed on November $16^{\text {th }}, 2018$.

FERREIRA MM AND SANTOS CR. 2011. Plágio: concepções e práticas textuais de pós-graduandos. In: Simpósio Internacional de Estudos dos Gêneros Textuais, Natal. Proceedings..., Natal: Associação Internacional de Linguística Aplicada.

FISHER RA. 1922. On the interpretation of chi square from contingency tables, and the calculation of PJR. Statist Soc 85: 87-94.

FOLTÝNEK T, RYBIČKA J AND DEMOLIOU C. 2014. Do students think what teachers think about plagiarism? International Journal for Educational Integrity 10(1): 2130 .

GILMORE J, STRICKLAND D, TIMMERMAN B, MAHER M AND FELDON D. 2010. Weeds in the flower garden: An exploration of plagiarism in graduate students' research proposals and its connection to enculturation, ESL, and contextual factors. International Journal for Educational Integrity 6(1): 13-28.

GREEN SP. 2002. Plagiarism, Norms, and the Limits of Theft Law: Some Observations on the Use of Criminal Sanctions in Enforcing Intellectual Property Rights. Hastings Law J 54(1): 167-242.

HABIBZADEH F AND SHASHOK K. 2011. Plagiarism in scientific writing: words or ideas? Croat Med J 52(4): 576577.

HARRIS R. 2001. The plagiarism handbook. Los Angeles: Pyrczak Publishing.

HOWARD RM. 2001. Plagiarism: What should a teacher do? Paper presented at the Conference on College Composition and Communication, Denver.

LOUI MC. 2002. Seven ways to plagiarise: handling real allegations of research misconduct. Sci Eng Ethics 8(4): 529-539.

MAXWELL A, CURTIS GJ AND VARDANEGA L. 2008. Does culture influence understanding and perceived seriousness of plagiarism? International Journal for Educational Integrity 4(2): 25-40. 
MCCABE D AND TREVIÑO LK. 1997. Individual and contextual influences on academic dishonesty: A multicampus investigation. Research in Higher Education 38(3): 379-396.

MCCABE DL, BUTTERFIELD K AND TREVIÑO LK. 2006. Academic Dishonesty in Graduate Business Programs: Prevalence, Causes, and Proposed Action. Academy of Management Learning \& Education 5(3): 294-305.

MCCABE DL AND PAVELA G. 2005. New honor codes for a new generation. Available at: https://www.insidehighered. com/views/2005/03/11/new-honor-codes-new-generation. Accessed on November $16^{\text {th }}, 2018$.

MCCABE DL, TREVIÑO LK AND BUTTERFIELD KD. 2001. Cheating in Academic Institutions: A Decade of Research. Ethics Behav 11(3): 219-232.

MCCABE DL, TREVIÑO LK AND BUTTERFIELD KD. 2002. Honor Codes And Other Contextual Influences On Academic Integrity: A Replication and Extension to Modified Honor Code Settings. Research in Higher Education 43(3): 357-379.

MOORE E. 2013. Sloppy referencing and plagiarism in student's theses. In: Mendel University in Brno. Plagiarism across Europe and Beyond. Conference Proceedings..., Brno, Czech Republic.

PEARSON K. 1992. On the Criterion that a Given System of Deviations from the Probable in the Case of a Correlated System of Variables is Such that it Can be Reasonably Supposed to have Arisen from Random Sampling. In: Kotz S and Johnson NL (Eds), Breakthroughs in Statistics. Springer Series in Statistics (Perspectives in Statistics). Springer, New York, NY.

PECORARI D. 2003. Good and original: Plagiarism and patchwriting in academic second-language. J Second Lang Writ 12(4): 317-345.

PLAGIARISM.ORG. 2013. Types of plagiarism. Available at: http://www.plagiarism.org/understanding-plagiarism. Accessed on November $16^{\text {th }}, 2018$.

POWER LG. 2009. University Students' Perceptions of Plagiarism. J High Educ 80(6): 643-662.

ROIG M. 2006. Commentary: Ethical writing should be taught. BMJ 333(7568): 596-597.

ROIG M. 2011. Avoiding plagiarism, self-plagiarism, and other questionable writing practices: A guide to ethical writing. Available at: http://ori.hhs.gov/sites/default/files/ plagiarism.pdf. Accessed on November $16^{\text {th }}, 2018$.

SANTOS CC, SANTOS PS, SANT'ANA MC, MASUDA H, BARBOZA MB AND VASCONCELOS SMR. 2017. Going Beyond Academic Integrity Might Broaden our Understanding of Plagiarism in Science Education: A Perspective from a Study in Brazil. An Acad Bras Cienc 89: 757-771.

SAUTHIER M, ALMEIDA FILHO AJ, MATHEUS MP AND LOPES PMF. 2011. Fraude e plágio em pesquisa e na ciência: motivos e repercussões. Revista de Enfermagem Referência 3(3): 47-55.

SILVA AKL AND DOMINGUES MJCS. 2008. Plágio no meio acadêmico: de que forma alunos de pós-graduação compreendem o tema. Perspectivas Contemporâneas 3(2): 117-135.

UNITED KINGDOM RESEARCH COUNCIL UK. 2011. RCUK Policy and Code of Conduct on the Governance of Good Research Conduct. Available at: https://www.ed.ac.uk/files/imports/fileManager/ RCUKPolicyandGuidelinesonGovernanceofGoo dResearchPracticeFebruary2013.pdf. Accessed on November $16^{\text {th }}, 2018$.

U.S. DEPARTMENT OF HEALTH AND HUMAN SERVICES. 2005. Public Health Service Policies on Research Misconduct. Federal Register 70(94): 2836928400.

VASCONCELOS S, LETA J, COSTA L, PINTO A AND SORENSON MM. 2009. Discussing plagiarism in Latin American Science. Brazilian researchers begin to address an ethical issue. EMBO Reports 10(7): 677-82.

\section{APPENDIX - SURVEY ON THE PERCEPTION REGARDING PLAGIARISM AMONG GRADUATE STUDENTS}

Dear student,

We are conducting a study on "Perception of the graduate students of the Universidade de São Paulo regarding the occurrence of plagiarism in the university environment". The study is conducted by a team of faculty members and officers of USP, coordinated by the Integrated Library System is a partnership with the Provost Office for Graduate Studies of the USP. The aim is to learn about the graduate students' perceptions regarding the practice of plagiarism in academic works and activities. We request your cooperation to respond to this questionnaire, which will take no longer than 10 minutes. We pledge to keep your participation confidential and we inform that the responses provided will be collectively analyzed, which makes personal or nominal identification unnecessary.

The questionnaires are to be returned by December 15, 2012.

We thank you for your attention and participation and we are ready to clear any 
necessary issues through the e-mail: dtsibi@usp.br Your participation is fundamental. Cooperate!

\section{SECTION A}

1. Plagiarism is: "Signing or presenting as yours (artistic or scientific work by someone else). Imitating (someone's work)".
( ) Fully agree
( ) Agree
( ) Indifferent
( ) Disagree
( ) Fully disagree

2. Literally copying (word by word) a paragraph from a text without making any identification of the source consulted is plagiarism.
( ) Fully agree
( ) Agree
( ) Indifferent
() Disagree
( ) Fully disagree

3. Writing a paragraph using sentences from other texts, presenting the sources consulted solely in the list of references at the end of the work is plagiarism.
( ) Fully agree
( ) Agree
( ) Indifferent
( ) Disagree
( ) Fully disagree

\section{Considering that ACCIDENTAL PLAGIARISM} may occur when students use someone else's contents but, for not knowing how to correctly indicate the author and to identify the source used, they eventually present those contents as if they were their own even though they belong to someone else... In your opinion, do students commit PLAGIARISM ACCIDENTALLY in academic works during their university studies?

$$
\text { ( ) Fully agree }
$$
( ) Agree
( ) Indifferent
( ) Disagree
() Fully disagree

5. In some situations, can students commit PLAGIARISM INTENTIONALLY, that is, using someone else's contents and presenting them as if they were their own, for example, they buy complete works, use colleagues' works, copy and paste in their works internet contents written by other people... In your opinion, do students commit PLAGIARISM INTENTIONALLY in academic works during their university studies?
( ) Fully agree
( ) Agree
( ) Indifferent
( ) Disagree
( ) Fully disagree

6. Along your graduate program, have you met a colleague who committed PLAGIARISM INTENTIONALLY when performing academic works?
( ) Yes, I have
( ) No, I have not

7. A student has handed in a piece of work in which half of the content was transcribed from a scientific work previously written by him/her. The new version had only a few items altered, such as date, name of discipline, introduction and conclusion. At no time was it clarified that the work content was practically the same as that from the other work written by the same student... In your opinion, has plagiarism occurred in the student's work?
( ) Fully agree
( ) Agree
( ) Indifferent
( ) Disagree
( ) Fully disagree 
8. Suppose a certain student has to hand in academic work in the next few days and has asked some friends to help and managed to find a work with the same theme already written and delivered by one of them. The student hands in that very same work, merely replacing the author's name and that of the institution. Is that plagiarism?
( ) Fully agree
( ) Agree
( ) Indifferent
( ) Disagree
( ) Fully disagree

9. A certain student has to hand in his academic work and knows a place where under-order works are sold. He buys and hands it in as if it had been written by him. Is that plagiarism?
( ) Fully agree
( ) Agree
( ) Indifferent
( ) Disagree
( ) Fully disagree

10. Among the reasons below, which do you consider to mostly influence the occurrence of plagiarism in academic works? Choose the alternative you consider the MOST IMPORTANT.

( ) A common practice among university students

( ) Ignorance of the rules for indicating and for identifying the sources consulted

( ) Eagerness to obtain good academic results (grades, outcomes...) regardless of the means

( ) Lack of time to carry out the required academic works

( ) Difficulty in writing texts

( ) Non-existence of control norms or penalties for committing plagiarism

( ) Easiness of copying from the Internet

( ) Other reasons:

11. In your opinion, which is the most efficient action to prevent plagiarism in academic activities?
Choose the alternative you consider the MOST ADEQUATE.

( ) Educational actions, directed towards prevention, such as lectures, talks, seminars

( ) Diagnostic actions to verify plagiarism by means of plagiarism prevention software

( ) Correction and punishment actions more rigorously applied at the institution

( ) Institutional actions, such as the adoption of honor codes, guidance handbooks and presentation of institutional policies

( ) I consider any type of action unnecessary

( ) Others:

12. At any point of the studies conducted so far, has the student learned how to make citations of and references to texts/research sources used in academic works?
() Yes
( ) No

13. Graduate students are capable of preventing plagiarism in academic works.
( ) Fully agree
() Agree
( ) Indifferent
( ) Disagree
( ) Fully disagree

14. Tick the actions adopted by the higher education institutions at which the respondent studied and which aimed to inform and to guide students towards preventing academic plagiarism. If necessary, tick more than one alternative:

( ) The institution had regulation, rules and penalties clearly informed to students

( ) At the institution, there were lectures on the plagiarism theme in some of the course discipline programs

( ) The institution handed out printed materials (guides, manuals, leaflets, posters) on academic plagiarism 
( ) The institution promoted talks on academic plagiarism

( ) The institution had an electronic page with information related to plagiarism

( ) I do not remember any specific activity adopted at the institution aiming to inform and to guide students towards preventing the occurrence of academic plagiarism

\section{SECTION B}

15. May a student use in his/her work, without any identification of the source, information considered of common knowledge, such as events, historical events and general knowledge of an area?
() Yes
( ) No
( ) I do not know

16. May a student elaborating the text of his/ her research report rewrite in his/her own words a reflection by another author without citing the source?
() Yes
( ) No
( ) I do not know

17. May a student literally transcribe a text from another source without using quotation marks or within reduced margins, provided he/she indicates the original source with the author-data or numerical system?
( ) Yes
( ) No
( ) I do not know

18. A student using a popular saying in his/her work

( ) Has to cite the source

( ) Does not has to cite the source

19. A student using in his/her work an image originally published in some other material

( ) Has to cite the source

( ) Does not has to cite the source
20. A certain author reuses integral parts of texts previously written and published by him/her in a new work to be submitted as original publication

( ) Has to cite the source

( ) Does not has to cite the source

21. When expressions and sentences from works considered of public domain, such as "to be or not to be, that is the question" or "I think, therefore I am" are used in an academic work, the student:

( ) Has to cite the source

( ) Does not has to cite the source

22. A student writing in his/her work, in his/her own words that "Galileu Galilei is considered the father of modern science for having developed the experimental method"

( ) Has to cite the source

( ) Does not has to cite the source

23. A student found the following text fragment in a research source: "human knowledge is created and expanded by means of social interaction between tacit knowledge and explicit knowledge. This interaction is called 'knowledge conversion"'. $\mathrm{He} / \mathrm{She}$ thus decided to simply use the phrase "knowledge conversion" in his/her work.

( ) Has to cite the source

( ) Does not has to cite the source

24. In a work under development, a student that synthesizes a piece of information about a recent research publicly broadcast on television

( ) Has to cite the source

( ) Does not has to cite the source

\section{SECTION C}

25 . What is your age range?

( ) from 20 to 25 years old

( ) from 26 to 30 years old

( ) from 31 to 35 years old

( ) from 36 to 40 years old

( ) above 41 years old 
26. What gender are you?
( ) Agricultural Sciences
( ) Exact and Earth Sciences
( ) Engineering
( ) Multidisciplinary

( ) Male

( ) Female

27. What is your graduate level?
( ) Professional master's student
( ) Academic master's student
( ) $\mathrm{PhD}$ student

29. In what country have you lived most of your life?
( ) Brazil
( ) Others:

program?
( ) Humanities
( ) Applied Social Sciences
( ) Linguistics, Languages and Arts
( ) Health Sciences
( ) Biological Sciences

30. What is your current occupational situation?
( ) Full-time student with a scholarship
( ) Full-time student without a scholarship
( ) Part-time job
( ) Full-time job 